\title{
Pengukuran Efektifitas Pembelajaran Kewirausahaan Dalam Meningkatkan Minat dan Tindakan Berwirausaha Mahasiswa
}

\author{
Agussalim Rahman ${ }^{1}$, Muhammad Amir ${ }^{2}$ \\ ${ }^{1,2}$ STIE Tri Dharma Nusantara - Makassar \\ email : agus.stietdn@gmail.com
}

Received: 22 September 2020; Accepted: 25 November 2020; Published: 15 Desember, 2020

\begin{abstract}
Abstrak
Tujuan dari penelitian ini adalah untuk mengetahui efektifitas pembelajaran kewirausahaan dalam meningkatkan minat dan tindakan berwirausaha mahasiswa yang telah mengikuti perkuliahan kewirausahaan. Responden penelitian adalah mahasiswa STIE Tri Dharma Nusantara kelas AKC-1 dan AKC-2 sebanyak 94 orang yang mengikuti mata kuliah Kewirausahaan pada semester V (pendek) 2020. Pendekatan penelitian adalah kombinasi antara pendekatan kuantitatif dan pendekatan kualitatif. Dalam penelitian ini peneliti menggunakan data yang berbentuk numerik atau angka yang jawaban responden dibuat dalam bentuk skala Likert. Pengukuran efektifitas variabel penelitian dilakukan dengan menggunakan teknik analisis statistik deskriptif dengan membandingkan skor aktual terhadap skor ideal terhadap masing-masing indicator penelitian. Hasil analisis terhadap total skor indikator indikator minat berwirausaha mencapai 81,29\% sehingga pembelajaran kewirausahaan sangat efektif membangkitkan minat berwirausaha di kalangan mahasiswa. Indicator tindakan (action) berwirausaha yang diukur dengan adanya aktivitas berwirausaha para mahasiswa hanya mencapai skor $10,28 \%$ yang berarti pembelajaran kewirausahaan tidak efektif membuat mahasiswa melakukan tindakan wirausaha.
\end{abstract}

Kata Kunci : Efektifitas, Kewirausahaan, Minat, Tindakan, Wirausaha

Abstract
The aims of this study was to determine the effectiveness of entrepreneurship learning in increasing the entrepreneurial interest and actions of students who have taken entrepreneurship courses. Research respondents were 94 students of STIE Tri Dharma Nusantara class AKC-1 and AKC-2 who took Entrepreneurship courses in V semesters (shortterm) 2020 .The research approach is a combination of a quantitative approach and a qualitative approach. In this study, researchers used numerical or numeric data in which respondents' answers were made in the form of a Likert scale. Measurement of the effectiveness of research variables was carried out using descriptive statistical analysis techniques by comparing the actual score against the ideal score against each research indicator. The results of the analysis of the total score of the indicator of the interest in entrepreneurship indicator reached $81.29 \%$ so that entrepreneurship learning was very effective in arousing interest in entrepreneurship among students. The indicator for entrepreneurial action which is measured by the presence of entrepreneurial activities of students only reaches a score of $10.28 \%$, which means that entrepreneurial learning is not effective in making students take entrepreneurial actions.

Keywords: effectiveness ; entrepreneurship ; interest ; action 


\section{PENDAHULUAN}

Krisis ekonomi yang terjadi pada tahun 1998 memberikan tekanan yang cukup berat pada dunia usaha di Indonesia. Terjadinya PHK besar-besaran dan krisis perekonomian meningkatkan jumlah pengangguran termasuk angkatan kerja lulusan perguruan tinggi yang terdidik.Wirausahawan di Indonesia jumlahnya hanya sekitar 1,65 \%. Masih dibutuhkan 1,7 juta wirausahawan baru supaya bisa mencapai angka ideal yaitu $2 \%$ dari penduduk adalah wirausahawan.Untuk itu sejak tahun 2000an pemerintah mulai menggalakkan kegiatan kewirausahaan melalui perguruan tinggi dengan memasukkan mata kuliah kewirausahaan dalam kurikulum pendidikan yang bertujuan untuk merubah pola fikir (mindset) mahasiswa baik mental maupun motivasinya.

Meskipun demikian, jumlah pengangguran dari lulusan perguruan tinggi cenderung mengalami peningkatan dari tahun ke tahun. Tahun 2013 mencapai 434.185 orang terus meningkat 495.143 orang pada tahun 2014. Kemudian meningkat lagi menjadi 653.586 orang pada tahun 2015. Pada Agustus 2019 telah mencapai 737 orang atau 5, $67 \%$ dari total angkatan kerja saat itu yang mencapai sekitar 13 juta orang. Kondisi ini lebih diperparah dengan menyebarnya wabah Covid-19 menyebabkan interaksi antar manusia semakin terbatas yang pada akhirnya dunia usaha kembali melakukan PHK terhadap tenaga kerjanya.Hal ini bertolak belakang dengan tujuan pembelajaran Kewirausahaan di perguruan tinggi yang dimaksudkan untuk merubah pola fikir para sarjana yang akan berlomba menjadi pegawai negeri agar menjadi wirausahawan yang membuka lapangan pekerjaan.

Dengan latar belakang kondisi obyektif ini membuat peneliti tertarik untuk mengukur efektifitas pembelajaran kewirausahaan di perguruan tinggi dalam meningkatkan minat dan tindakan berwirausaha di kalangan mahasiswa Tujuan dari penelitian ini adalah untuk mengukur efektifitas pembelajaran kewirausahaan di dalam meningkatkan minat berwirausaha serta tindakan berwirausaha para mahasiswa di kampus dengan mengambil studi kasus pada STIE Tri Dharma Nusantara Makassar. 
Menurut (Rusdiana, 2014), kewirausahaan adalah semangat, sikap, perilaku, dan kemampuan seseorang dalam menangani usaha atau kegiatan yang mengarah pada upaya mencari, menciptakan serta menerapkan cara kerja, teknologi dan produk baru dengan meningkatkan efisiensi dalam rangka memberikan pelayanan yang lebih baik dan/atau memperoleh keuntungan yang lebih besar. Sementara Pendidikan/ pembelajaran yang berwawasan kewirausahaan adalah pendidikan yang menerapkan prinsip prinsip dan metodologi ke arah pembentukan kecakapan hidup (life skill) pada peserta didiknya melalui kurikulum yang terintegrasi yang dikembangkan di sekolah (A. Wibowo, 2011). Pembelajaran kewirausahaan dapat didefinisikan sebagai usaha yang dilakukan lembaga pendidikan untuk menanamkan pengetahuan, nilai, jiwa dan sikap kewirausahaan kepada mahasiswa dan peserta didik guna membekali diri menjadi manusia yang mandiri, kreatif dan inovatif. Hal ini juga bertujuan untuk menciptakan wirausahawirausaha baru yang handal dan berkarakter dan dapat meningkatkan kesejahteraan masyarakat.(Susilaningsih, 2015). Mata kuliah kewirausahaan adalah mata kuliah wajib bagi mahasiswa semester 5 pada semua program studi di STIE Tri Dharma Nusantara yang diajarkan pada semester pendek dengan durasi 2 bulan sebanyak 16 jam pertemuan. Tujuan yang akan dicapai melalui pembelajaran kewirausahaan adalah agar para mahasiswa memahami latar belakang pentingnya belajar kewirausahaan, memahami langkah praktis menjalankan usaha, memahami langkah langkah teknis dalam menjalankan usaha serta memotivasi mahasiswa untuk melakukan aktifitas berwirausaha.

Minat Berwirausaha

Menurut (Helmi, 2016), mendefinisikan minat wirausaha adalah gejala psikis untuk memusatkan perhatian dan berbuat sesuatu terhadap wirausaha itu dengan perasaan senang karena membawa manfaat bagi dirinya. Menurut (Hutabarat, 2017), minat berwirausaha merupakan pemusatan perhatian pada wirausaha karena adanya rasa suka dan disertai keinginan mempelajari, mengetahui dan membuktikan lebih lanjut terhadap wirausaha. Minat berwirausaha muncul karena adanya pengetahuan dan informasi mengenai kewirausahaan yang kemudian dilanjutkan untuk berpartisipasi secara langsung dalam rangka mencari pengalaman 
dan akhirnya timbul keinginan untuk memperhatikan pengalaman yang telah didapatkan tersebut. Serta mempunyai perasaan senang dan mempunyai keinginan untuk terlibat dalam kegiatan pengambilan resiko, untuk menjalankan bisnis atau usaha sendiri dengan memanfaatkan peluangpeluang bisnis yang ada, dan menciptakan bisnis baru dengan pendekatan inovatif. Minat berwirausaha tidak dimiliki dengan begitu saja, melainkan dapat dipupuk dan dikembangkan.(Siswadi, 2013). Minat adalah kecenderungan untuk merasa tertarik atau terdorong untuk memperhatikan sesuatu obyek atau kegiatan dalam bidang tertentu. (Rahmadi \& Heryanto, 2017) Berdasarkan beberapa pendapat diatas dapat diambil kesimpulan bahwa minat adalah suatu kecenderungan atau keinginan yang membuat orang merasa tertarik pada suatu obyek atau aktivitas tertentu dimana subyek merasa senang melakukannya. Minat berwirausaha merupakan keinginan, ketertarikan, serta kesediaan individu untuk bekerja keras dalam memenuhi kebutuhan hidupnya tanpa takut dengan resiko yang akan terjadi. (Puspitaningsih, 2014)

Tindakan Wirausaha

Tindakan adalah mekanisme dari suatu pengamatan yang muncul dari persepsi sehingga ada respon untuk mewujudkan suatu perbuatan. (Notoadmodjo, 2007). Sehingga tindakan adalah manifestasi dari keinginan yang diwujudkan dalam bentuk perbuatan (aksi). Dengan demikian maka tindakan berwirausaha adalah perbuatan, aktivitas, aksi nyata dalam melakukan kegiatan usaha yang ditunjukkan dengan memantapkan keinginan, mematangkan rencana usaha, mengkombinasikan sumber daya serta dimulainya kegiatan usaha (bisnis ). Aktivitas kewirausahaan dimaknai sebagai aktivitas individu dalam memulai bisnis baru dan dinyatakan dalam persentase total penduduk yang aktif bekerja (bisnis). Semakin tinggi tingkat aktivitas kewirausahaan (enterpreneurship activity) maka semain tinggi entrepreneur level sebuah Negara. Boulton dan Turner dalam (Hendarman, 2011). Tindakan berwirausaha tidak cukup hanya dengan mendapatkan pembelajaran kewirausahaan dalam kelas. Perubahan dari berminat menjadi tindakan banyak dipengaruhi oleh factor lain.

\section{METODE PENELITIAN}

JPEK, Vol. 4, No. 2 Desember 2020. 220 
Pendekatan penelitian yang digunakan adalah kombinasi antara pendekatan kuantitatif dan pendekatan kualitatif. Penelitian kuantitatif digunakan karena variable penelitian sudah jelas dengan membandingkan antara tujuan/target yang ditunjukkan dengan skor ideal dengan fakta/hasil yang ditunjukkan dengan skor actual. Dalam penelitian kuantitatif, peneliti menggunakan data yang berbentuk numerik atau angka yang jawaban responden dibuat dalam bentuk skala Likert.(Sugiyono, 2014)

Skala Likert digunakan untuk mengukur sikap, pendapat dan persepsi obyek penelitian tentang fenomena sosial yang menjadi variable penelitian. Dengan skala likert, variable yang akan diukur dijabarkan menjadi indicator penelitian. Kemudian indicator tersebut dijadikan titik tolak untuk menyusun item item instrument yang dapat berupa pertanyaan atau pernyataan. Jawaban setiap item instrument yang menggunakan skala likert mempunyai gradasi dari sangat positif sampai sangat negatif dengan memakai skor 5 sampai 1 ataupun sebaliknya dari yang sangat negative sampai yang sangat positif dengan memakai skala $1-5$. Skala jawaban responden tergantung pada jenis pertanyaan apakah berbentuk pertanyaan positif atau pertanyaan negatif.

Pendekatan kualitatif digunakan karena peneliti akan berinteraksi langsung dengan responden agar masalah penelitian bisa ditemukan dengan jelas. Data penelitian diperoleh dari jawaban responden terhadap instrument penelitian (kuesioner). Jumlah responden sebanyak 94 orang yang merupakan mahasiswa STIE Tri Dharma Nusantara yang mengikuti mata kuliah kewirausahaan pada Semester V Pendek 2020.

Kuesioner minat berwirausaha terdiri atas 38 pertanyaan dimana 19 pertanyaan positif dan 19 pertanyaan negatif. Sedangkan untuk mengukur tindakan berwirausaha terdiri atas 3 pertanyaan inti dan 2 pertanyaan tambahan. Daftar pertanyaan terdistribusi untuk menjawab indicator indicator penelitian.

Metode dalam pengumpulan data adalah tanggapan atas kuesioner/angket dikumpulkan melalui akun peneliti, kemudian ditabulasi, diamati (observasi) dan wawancara dengan cara yang mendalam (indepth interview) melalui Forum Discuccion Group (FGD) dengan beberapa perwakilan responden. Data kuantitatif JPEK, Vol. 4, No. 2 Desember 2020. 221 
yang terkumpul dari kuesioner akan ditabulasi untuk selanjutnya dianalisis dengan menggunakan teknik analisis statistik deskriptif dengan membandingkan skor aktual terhadap skor ideal pada masing-masing indicator penelitian. Untuk mengukur efektifitas pembelajaran kewirausahaan dalam meningkatkan minat maupun tindakan berwirausaha mahasiswa maka peneliti mempergunakan standar kualifikasi berikut :

Tabel 2 :

Standar kualifikasi efektifitas

\begin{tabular}{lll}
\hline No & Rasio Efektifitas $(\%)$ & Kualifikasi \\
\hline 1 & $0,00-0,20$ & Tidak efektif \\
\hline 2 & $0,21-0,40$ & Kurang Efektif \\
\hline 3 & $0,41-0,60$ & Cukup Efektif \\
\hline 4 & $0,61-0,80$ & Efektif \\
\hline 5 & $0,81-1,00$ & Sangat Efektif \\
\hline
\end{tabular}

Selanjutnya untuk memahami interaksi social dari para responden maka peneliti melakukan penelitian dengan metode kualitatif dengan cara ikut berperan aktif dalam melakukan wawancara mendalam dengan interaksi terhadap responden agar ditemukan pola hubungan variable penelitian dengan jelas.

\section{HASIL PENELITIAN DAN PEMBAHASAN}

\section{Hasil Penelitian}

Hasil penelitian terhadap 94 responden menunjukkan skor capaian yang beragam. Perincian rekapitulasi pengukuran efektifitas pembelajaran kewirausahaan terhadap minat dan tindakan wirausaha sebagai berikut :

Tabel 3 :

Pengukuran Efektifitas Pembelajaran Kewirausahaan

Terhadap Minat Berwirausaha Mahasiswa

\begin{tabular}{lrrrrr}
\hline No & Indikator & Aktual & Ideal & Capaian & Kualifikasi \\
\hline 1 & Rasa percaya diri & 2.985 & 3.760 & $79,31 \%$ & Efektif \\
\hline
\end{tabular}




\begin{tabular}{rlrrrl}
\hline 2 & Berani mengambil resiko & 2.297 & 2.820 & $81,45 \%$ & Sangat Efektif \\
\hline 3 & Kreatif \& inovatif & 1.543 & 1.880 & $82,07 \%$ & Sangat Efektif \\
\hline 4 & Disiplin dan kerja keras & 1.550 & 1.880 & $82,45 \%$ & Sangat Efektif \\
\hline 5 & Orientasi ke masa depan & 2.302 & 2.820 & $81,63 \%$ & Sangat Efektif \\
\hline 6 & Rasa ingin tahu & 1.565 & 1.880 & $83,24 \%$ & Sangat Efektif \\
\hline 7 & Jujur dan mandiri & 2.279 & 2.820 & $80,82 \%$ & Sangat Efektif \\
\hline & Total & $\mathbf{1 4 . 5 1 8}$ & $\mathbf{1 7 . 8 6 0}$ & $\mathbf{8 1 , 2 9 \%}$ & Sangat Efektif \\
\hline
\end{tabular}

Tabel 4 :

Pengukuran Efektifitas Pembelajaran Kewirausahaan

Terhadap Tindakan Berwirausaha Mahasiswa

\begin{tabular}{cccccl}
\hline No & Indikator & Aktual & Ideal & Capaian & \multicolumn{1}{c}{ Kualifikasi } \\
\hline 1 & Sudah memulai usaha & 12 & 94 & $12,77 \%$ & Tidak Efektif \\
\hline 2 & Memiliki produk/jasa & 9 & 94 & $9,57 \%$ & Tidak Efektif \\
\hline 3 & Ada aktifitas pemasaran & 8 & 94 & $8,51 \%$ & Tidak Efektif \\
\hline & Total & $\mathbf{2 9}$ & $\mathbf{2 8 2}$ & $\mathbf{1 0 , 2 8} \%$ & Tidak Efektif \\
\hline
\end{tabular}

\section{Pembahasan}

Hasil pengukuran menunjukkan bahwa indicator peningkatan minat berwirausaha yang terendah adalah rasa percaya diri mahasiswa. Rendahnya rasa percaya diri ini muncul karena kebanyakan mahasiswa merasa belum memiliki keyakinan untuk mampu melakukan tindakan wirausaha

Skor indicator tertinggi yang meningkatkan minat mahasiswa untuk berwirausaha adalah rasa ingin tahu. Penjelasan mengenai latar belakang pentingnya mahasiswa untuk merubah mindset untuk menjadi wirausahawan ternyata sangat efektif meningkatkan minat mahasiswa untuk berwirausaha.

Secara umum, indicator indicator minat berwirausaha menunjukkan bahwa pembelajaran kewirsausahaan sangat efektif dalam meningkatkan minat berwirausaha di kalangan mahasiswa. Kecuali indikator " rasa percaya diri " yang kualifikasinya efektif dalam meningkatkan minat berwirausaha.

Pengukuran pada indicator tindakan berwirausaha menunjukkan hanya 12 orang atau $12,77 \%$ responden yang sudah memulai usaha dan 82 orang lainnya 
hanya berminat tetapi tidak melanjutkan menjadi tindakan berwirausaha. Dari 12 orang yang sudah memulai usaha, baru 8 orang atau $8,51 \%$ yang sudah melakukan aktifitas pemasaran/penjualan.

\section{KESIMPULAN}

Hasil analisis terhadap skor indikator minat berwirausaha yaitu mahasiswa telah memiliki rasa percaya diri dengan skor 79,31\%, keberanian mengambil resiko $81,45 \%$, kreativitas dan inovatif 82,07 \%, Disiplin dan kerja keras 82,45 \%, orientasi masa depan 81,63\%, rasa ingin tahu 83,24 \% dan kejujuran dan kemandirian sebesar 80,82\%. Skor total indicator indicator minat berwirausaha mahasiswa mencapai 81,29 \%. Dengan demikian maka pembelajaran kewirausahaan terbukti efektif membangkitkan minat berwirausaha mahasiswa.

Meskipun demikian, skor indicator tindakan (action) berwirausaha yang diukur dengan adanya aktivitas berwirausaha para mahasiswa hanya mencapai $10,28 \%$ yang berarti pembelajaran kewirausahaan tidak efektif membuat mahasiswa melakukan tindakan wirausaha. Penyebab utamanya adalah masih rendahnya rasa percaya diri mahasiswa untuk memulai usaha sebagai akibat dari kurangnya kesempatan untuk ujicoba berwirausaha.

Diperlukan mata kuliah atau program lanjutan yang memungkinkan mahasiswa mengikuti praktek wirausaha sehingga minat yang sudah bangkit saat mengikuti perkuliahan kewirausahaan bisa teraktualisasi dalam bentuk tindakan.

\section{DAFTAR RUJUKAN}

Alma, B. (2013). Kewirausahaan (Cetakan 19). Alfabeta.

Diyanti, I. S., \& Soejoto, A. (2015). Pengaruh Hasil Belajar Mata Pelajaran Kewirausahaan Dan Lingkungan Keluarga Terhadap Minat Berwirausaha Siswa SMK Gema 45 Surabaya. Statewide Agricultural Land Use Baseline $2015,1,1-18$.

Helmi, A. F. (2016). Kewirausahaan Di Perguruan Tinggi Dalam Perspektif Psikologi. Kewirausahaan Di Perguruan Tinggi Dalam Perspektif Psikologi, $17(2), 57-65$

Hendarman. (2011). Kajian Kebijakan PMW (Program Mahasiswa Wirausaha). Jurnal Pendidikan Dan Kebudayaan, 17(6), 635. 
Hutabarat, Z. (2017). Minat Mahasiswa Untuk Menjadi Wirausahawan. Jurnal Akuntansi Dan Manajemen, II(7), 22-28.

Kasmir. (2013). Kewirausahaan. RajaGrafindo Persada.

Notoadmodjo. (2007). Pendidikan dan Perilaku (Cetakan 2). Rineka Cipta.

Puspitaningsih, F. (2014). Pengaruh Efikasi Diri dan Pengetahuan Kewirausahaan Terhadap Minat Berwirausaha Melalui Motivasi. Ekonomi Pendidikan Dan Kewirausahaan, Vol. 2 No.

Rahmadi, A. N., \& Heryanto, B. (2017). Analisis Faktor-Faktor Yang Mempengaruhi Minat Berwirausaha Pada Mahasiswa Program Studi Manajemen Fakultas Ekonomi Universitas Kadiri. Ekonika : Jurnal Ekonomi Universitas Kadiri, 1(2), 153-169

Rusdiana. (2014). Kewirausahaan, Teori dan Praktik. Pustaka Setia.

Siswadi, Y. (2013). Analisis Faktor Internal, Faktor Eksternal dan Pembelajaran Kewirausahaan Yang Mempengaruhi Minat Mahasiswa Dalam Berwirausaha. Manajemen \& Bisnis, Vol. 13 No.

Sugiyono. (2014). Metode Penelitian Kombinasi (Mixed Methods). Alfabeta.

Suryana. (2013). Kewirausahaan, Kiat \& Proses Menuju Sukses (Edisi 4). Salemba Empat.

Susilaningsih, S. (2015). Pendidikan Kewirausahaan Di Perguruan Tinggi: Pentingkah Untuk Semua Profesi? Jurnal Economia, 11(1)

Wedayanti, N., \& Giantari, I. (2016). Peran Pendidikan Kewirausahaan Dalam Memediasi Pengaruh Norma Subyektif Terhadap Niat Berwirausaha. E-Jurnal Manajemen Universitas Udayana, 5(1), 255039.

Wibowo, A. (2011). Pendidikan Kewirausahaan. Pustaka Pelajar.

Wibowo, M. (2011). Pembelajaran Kewirausahaan dan Minat Wirausaha Lulusan SMK. Eksplanasi, 6(2), 109-122.

Wirausaha, M., Santri, K., \& Ulfa, N. (2016). Minat Wirausaha Kaum Santri Dan Faktor-Faktor Yang Mempengaruhinya (Studi Pada Pondok Pesantren ArRiyadh Palembang). I-Economics, 1(1), 91-121. 